\section{Pro-inflammatory Analysis of Macrophages in Contact with Titanium Particles and Porphyromonas gingivalis}

Cindy Goes Dodo ${ }^{1}$, Luiz Meirelles ${ }^{2}$ Alejandro Aviles-Reyes ${ }^{3}$, Karina Gonzalez

Silvério Ruiz ${ }^{1}$, Jacqueline Abranches ${ }^{3}$, Altair Antoninha Del Bel Cury ${ }^{1}$

\author{
'Department of Prosthodontics \\ and Periodontology, Dental \\ School of Piracicaba, UNICAMP \\ - Universidade Estadual de \\ Campinas, Piracicaba, SP, Brazil \\ ${ }^{2}$ American Dental Association, \\ Chicago, IL, USA \\ ${ }^{3}$ University of Florida, \\ Gainesville, FL, USA
}

Correspondence: Altair Antoninha Del Bel Cury, Avenida Limeira, 901, 13414-903 Piracicaba, SP, Brasil. Tel: +55-19-2106-5294. e-mail: altcury@fop.unicamp.br

Key Words: osteolysis, dental implant, cytokines, bone resorption, titanium.

\begin{abstract}
During insertion of titanium dental implants, particles may shear from the implant to the periimplant region causing osteolysis, and their association with bacteria can exacerbate the inflammatory reaction. However, the association of a high invasive bacterium from the oral cavity, Porphyromonas gingivalis $(\mathrm{Pg})$, and titanium particles remains unknown. This study evaluated pro-inflammatory reaction of human macrophages in contact with micro and nanoparticles of titanium associated with Porphyromonas gingivalis lipopolysaccharide (PgLPS). THP-1 cell were used and treated for 12, 24 and $48 \mathrm{~h}$ following 6 groups: Control(C), PgLPS (L); Microparticles (M); Nanoparticles (N); PgLPS and microparticles (LM); PgLPS and nanoparticles (LN). The following assays were carried out: i) cell viability using MTS, ii) cell morphology by SEM and iii) expression of tumor necrosis factor alpha (TNF- $\alpha$ ), interleukin-1 beta (IL-1 $\beta$ ) and interleukin-6 (IL-6) by qRT-PCR and ELISA. For statistics two-way ANOVA followed by Tukey's test was used $(p<0.05)$. After treatment, cells presented similar viability and morphology demonstrating that the treatments were not able to induce cell death. Gene expression was significantly higher for TNF- $\alpha$ and IL1- $\beta$ after $12 \mathrm{~h}$, and for IL-6 after $24 \mathrm{~h}$ in the $\mathrm{N}$ and LN groups. Cytokine production over time was an ascending curve for TNF- $\alpha$ with the peak at 48 $\mathrm{h}$ and IL1- $\beta$ and IL-6 had a straight line among the time points, although cells from $\mathrm{N}$ group presented a significant production of IL-6 at $48 \mathrm{~h}$. In conclusion, these results suggest that titanium nanoparticles stimulate stronger pro-inflammatory response in macrophages, independent of their association with LPS from P.gingivalis.
\end{abstract}

\section{Introduction}

Titanium implants are most used for dental rehabilitation and their surface properties have been modified to enhance cellular response, usually by increasing the surface roughness (1). Modifications on implant surfaces are an attempt to increase their primary stability and improve the osseointegration process (1). Previous studies by our research group demonstrated that during insertion into bone, the peaks created to increase surface roughness are prone to break, culminating in the release of titanium microparticles and nanoparticles, especially in the cortical region near the neck of the implant $(2,3)$. Histological analyses also showed that titanium particles can be trapped in peri-implant tissue even after 6 months of implant placement (4).

While the presence of titanium particles shed from titanium surfaces during dental implant insertion in the cortical region was proven, the consequences related to the presence of these particles in the dental peri-implant tissue were poorly investigated. Orthopedic studies showed that the presence of titanium particles from wear of limb prosthesis could over-express pro-inflammatory cytokines such as IL-6, TNF- $\alpha$ and IL1- $\beta$, that are related to the osteolysis process, culminating in bone loss around the implant and prosthesis failure (5). Furthermore, the orthopedic studies showed that presence of bacterial endotoxin in the implant could intensify the inflammatory reaction, increasing bone loss $(6,7)$.

In the peri-implant region there is a natural microbiota usually similar to the oral cavity before implant installation (8). Porphyromonas gingivalis is a key pathogen for periodontal diseases (9) and a bacterium reported to be in the dental peri-implant region after dental implant installation $(8,10)$. Thus, it is important to assess the influence of titanium microparticles and nanoparticles released from dental implant surfaces during insertion, associated with endotoxins from bacteria in the periimplant area. Hence, an in vitro study was proposed to evaluate the pro-inflammatory reaction of macrophages, the first cell lineage interacting with a foreign body, in the presence of titanium microparticles and nanoparticles associated with lipopolysaccharide from $P$. gingivalis, regarding gene expression and protein production of proinflammatory cytokines related to the osteolysis process. 


\section{Materials and Methods}

\section{Titanium Particles}

Microparticles of titanium powder CAS 7740-32-6 ( $<20$ micron, 93\%, Alfa Aesar, Ward Hill, MA, USA) and titanium (IV) oxide nanoparticles CAS 13463-67-7 (21 $\mathrm{nm}$, Sigma Aldrich, St Louis, MO, USA) were used in this study. The particles were weighted and separated in 15 $\mathrm{mL}$ tubes (Fischer Scientific, Waltham, Massachusetts, USA) containing $25 \mathrm{mg}$ each. A cleaning procedure was required to certify that the particles were not contaminated with amounts of endotoxin (10-20 units $/ \mathrm{mL}$ ) as previously reported $(6,7,11)$. The particles were cleaned using $25 \%$ nitric acid for $2 \mathrm{~h}$ followed by 3 washes in phosphatebuffered saline (PBS) (Invitrogen, Waltham, MA, USA) for 5 min each and placed in 95\% ethanol with $0.1 \mathrm{~N}$ of $\mathrm{NAOH}$ for $24 \mathrm{~h}$, followed by 3 washes in PBS $(6,12)$. After the cleaning procedure, the presence of endotoxins was measured using Limulus Amebocyte Lysate Chromogenic Endotoxin Quantification Kit (Thermo Fisher Scientific, Grand Island, NY, USA) following the manufacturer's protocol. The presence of endotoxins was $<0.01$ endotoxin units $/ \mathrm{mL}$, confirming the effectiveness of the cleaning procedure (11). The particles were maintained in PBS 25 $\mathrm{mg} / \mathrm{mL}$ at $4{ }^{\circ} \mathrm{C}$, and the solution was agitated for $20 \mathrm{~min}$ prior to each use (13).

\section{Cell Culture}

Human monocyte THP-1 cells $\left(5 \times 10^{5}\right.$ cells/well) (ATCC ${ }^{\circledR}$ TIB-202 ${ }^{\mathrm{TM}}$; American Type Culture Collection, Manassas, VA, USA) were placed in a 6-well plate with RPMI-1640 medium, supplemented with 10\% fetal bovine serum and 1\% penicillin-streptomycin antibiotics (Invitrogen, Carlsbad, CA, USA) in an incubator with $5 \% \mathrm{CO}_{2} / 95 \%$ air at $37^{\circ} \mathrm{C}$. The cells were differentiated to macrophages using $125 \mathrm{ng} /$ well for $48 \mathrm{~h}$ of phorbol 12 - myristate 13 - acetate (PMA) (Sigma Aldrich, St. Louis, MO, USA) (14). The wells were washed 3 times with PBS and treated according to the following 6 experimental groups: no treatment, Control (C); $1 \mu \mathrm{g} / \mathrm{mL}$ lipopolysaccharide from P. gingivalis (L) (15); 50 $\mathrm{ng} / \mathrm{mL}$ of titanium microparticles (M); $50 \mathrm{ng} / \mathrm{mL}$ titanium nanoparticles $(\mathrm{N}) ; 1 \mu \mathrm{g} / \mathrm{mL}$ of lipopolysaccharide from $P$. gingivalis plus $50 \mathrm{ng} / \mathrm{mL}$ microparticles (LM); $1 \mu \mathrm{g} / \mathrm{mL}$ of lipopolysaccharide from $P$. gingivalis plus $50 \mathrm{ng} / \mathrm{mL}$ of titanium nanoparticles (LN). The treatments were diluted in RPMI-1640 medium and $5 \mathrm{~mL}$ was placed in each well of a 6-well plate (12).

\section{Cell Viability in the Presence of Titanium Particles}

The cell viability analyses were performed to evaluate whether the proposed treatments were leading to cell death. After treatments for 12, 24 and $48 \mathrm{~h}$, the viability was verified in a spectrophotometer (Multiskan
Spectrum Microplate Spectrophotometer; Thermo Fisher Scientific Inc., MA, USA) at $490 \mathrm{~nm}$ using CellTiter $96^{\circledR}$ Aqueous One Solution Cell Proliferation Assay with tetrazolium compound [3- (4,5-dimethylthiazol-2-yl) -5-(3-carboxymethoxyphenyl)-2-(4-sulfophenyl)-2Htetrazolium, inner salt; MTS (Promega, WI, USA) following the manufacturer's instructions (16). The cells were also treated following the experimental groups on polysinecoated glass cover slips (ThemoScientific, Waltham, MA, USA) and prepared for scanning electron microscopy (SEM) analysis with 5\% Karnovisk overnight and dehydrated in successive concentrations of ethanol (50\%,70\%, 95\% and twice at 100\%) with $15 \mathrm{~min}$ incubations between each step. The samples were then critical point-dried using a critical point dryer (Critical Point Dryer, Seevac Inc, FL, USA). Each specimen was mounted on a SEM stub and sputter-coated with a conductive layer of AuPd. The samples were imaged using a JEOL JSM 5600 PV SEM (Akishima, Tokyo, Japan).

\section{Gene Expression Analysis}

After the incubation period following the experimental groups, the cells were harvested after 12, 24 and $48 \mathrm{~h}$. Also a baseline group $(0 \mathrm{~h})$ was prepared for gene expression data analysis. Total RNA was extracted using TRIzol Reagent (Invitrogen, Carlsbad, CA, USA) according to the recommended protocol and the quantity and quality of RNA obtained were analyzed by Nanodrop (ND-1000 Spectrophotometer; Wilmington, DE, USA) and an agarose $0.8 \%$ gel electrophoresis ( $40 \mathrm{~min}, 80 \mathrm{~mA}$ ). Total extracted RNA was cleaned using DNA-free ${ }^{\mathrm{TM}}$ DNA Removal Kit (Ambion; Life Technologies, Carlsbad, CA, USA) and purified using RNeasy Mini Kit (Qiagen, Valencia, CA, USA). The purified RNA ( $0.5 \mu \mathrm{g}$ of RNA per reaction) was converted to cDNA in a reverse transcriptase reaction using a PrimeScrip RT reagent kit (Qiagen). RT-PCR (100 ng of cDNA per reaction) was carried out using the PerfeCta SYBR Green FastMix Kit (Quanta Biosciences, Gaithersburg, MD, USA) and StepOnePlus real-time PCR system (Life Technologies) following 40 cycles of $95^{\circ} \mathrm{C}$ for $10 \mathrm{~s}$, and $60^{\circ} \mathrm{C}$ for $30 \mathrm{~s}$ and $95{ }^{\circ} \mathrm{C}$ for $10 \mathrm{~s}$. The comparative quantification algorithm $(\Delta \Delta \mathrm{Ct})$ method was used and the expression level of the internal control gene, Glyceraldehyde 3-phosphate dehydrogenase (GAPDH) was used to normalize the data. Experiments were performed in triplicate. The gene specific primers used in this study are in Table 1.

\section{Quantification of Cytokine Production}

The cell-free supernatant was collected from three independent experiments and the extracellular levels of cytokines TNF- $\alpha$, IL- $1 \beta$ and IL- 6 were measured using the Single-Analyte ELISArray Kits (Qiagen), following the manufacture protocol. The absorbance was on a 
spectrophotometer (Multiskan Spectrum Microplate Spectrophotometer, Thermo Fisher Scientific), and concentrations were calculated according to the standard curve of each cytokine.

\section{Statistical Analyses}

The results were analyzed by ANOVA followed by Tukey's at 5\% significance level SAS 7.0 statistical software (SAS, Cary, NC, USA)

\section{Results}

\section{Cell Viability and Gene Expression of Inflammatory Cytokines}

In order to verify whether the proposed treatments were able to cause cell death, metabolic activity as an indicator for cell viability was first measured using MTS assay. As shown in Figure 1, titanium particles ( $\mathrm{N}$ and $\mathrm{M}$ ) did not affect the proliferation of cells during the $48 \mathrm{~h}$ period, even after incubation with $1 \mu \mathrm{g} / \mathrm{mL}$ of LPS from $P$. gingivalis ( $p>0.05$ ). In addition, macrophages presented similar morphology after different treatments, as visualized by SEM (Fig. 2).

Next, a qRT-PCR was performed to assess gene $\Xi$ expression changes on pro-inflammatory cytokines IL-1 $\beta$, TNF- $\alpha$, IL- 6 in macrophages. The findings demonstrated that the expression of three cytokines was time and treatmentdependent (Fig. 3). The highest levels of transcripts for TNF- $\alpha$, IL- $1 \beta$ and IL- 6 were found in cells cultured with titanium nanoparticles $(\mathrm{N})$, followed by the group of cells exposed to PgLPS plus titanium nanoparticles (LN) at each time point (Fig. 3). After $12 \mathrm{~h}$ in culture, mRNA levels for TNF- $\alpha$ and IL- $1 \beta$ reached the maximum expression for all treatments. However, the expression of TNF- $\alpha$ mRNA was up-regulated more than eight-fold and six-fold for $\mathrm{N}$ and LN groups, respectively, whereas levels of IL- $1 \beta$ transcripts were significantly increased $(p<0.05)$ for cell exposure to titanium nanoparticles ( $\cong 12$ fold) compared to the other groups (Fig. 3). Regarding IL-6 cytokine, qRT-PCR analysis also demonstrated an increased expression for $\mathrm{N}$ and $\mathrm{LN}$ groups after $12 \mathrm{~h}$ of treatment (Fig. 3). Nevertheless, the treatment of macrophages with $\mathrm{N}$ and $\mathrm{LN}$ for $24 \mathrm{~h}$ led to

Table 1. Primers sequence used for amplification in real-time PCR

\begin{tabular}{lll}
\hline Gene & & Seq 5’to 3 \\
\hline GAPDH & F: CGAGATCCCTCCAAAATCAA & R:TTCACACCCATGACGAACAT \\
$I L-1 \beta$ & F:GGACAAGCTGAGGAAGATGC & R:TCGTTATCCCATGTGTCGAA \\
TNF- $\alpha$ & F: AGCCCATGTTGTAGCAAACC & R:TGAGGTACAGGCCCTCTGAT \\
$I L-6$ & F: CACAGACAGCCACTCACCTC & R:TTTTCTGCCAGTGCCTCTTT \\
\hline
\end{tabular}

GAPDH, glyceraldehyde-3-phosphate dehydrogenase; IL-1 $\beta$, interleukin- 1 beta; TNF- $\alpha$, tumor necrosis factor alpha; IL-6, interleukin 6. the highest levels of transcripts for IL-6 (ミeighty-fold and sixty-five-fold, respectively), confirming induction of proinflammatory reaction by these titanium nanoparticles.

Titanium microparticles also induced a proinflammatory response in macrophages characterized by increased expression of TNF- $\alpha$ and IL-6 cytokines (Fig. 3). However, this effect was smaller compared to titanium nanoparticles exposure, even in presence of LPS from $P$. gingivalis. Interestingly, the lower fold increase for all three cytokines was found in macrophages cultured under PgLPS challenge (Fig. 3).

\section{Cytokine Production}

Overall, cytokine production had an ascending curve for TNF- $\alpha$ and the peak occurred after $48 \mathrm{~h}$. For IL-1 $\beta$ and IL-6 the production was almost a straight line, with the exception for the production of IL- 6 for $\mathrm{N}$ group that had higher production at $48 \mathrm{~h}$.

The average high expression of cytokine was for IL1- $\beta$ followed by TNF- $\alpha$ and IL1-6 (Fig 4). The results showed that TNF- $\alpha$ production was greater at $48 \mathrm{~h}$ for the $\mathrm{N}$ group (2019.1 pg/mL) followed by the M, LPS and LN groups, which were significantly increased $(p<0.05)$ compared to control and LM groups (Fig. 4). The highest levels of protein production were observed for IL-1 $\beta$, but there were no significant differences among the groups. For IL-6 the highest protein production was also observed for the group treated with nanoparticles at $48 \mathrm{~h}(1301,82 \mathrm{pg} / \mathrm{mL})$. Overall, the groups treated with titanium micro and nanoparticles presented the highest protein production. The groups treated with titanium particles in association with PgLPS presented similar or less pro-inflammatory production than the groups treated just with titanium particles.

\section{Discussion}

The presence of titanium particles in the dental periimplant region can be an obstacle for bone regeneration, which may lead to marginal bone loss. The orthopedic literature showed the influence of titanium wear particles in the osteolytic process that cause implant failure and may be exacerbated in the presence of bacteria. This study investigated the behavior of human macrophages in the presence of titanium micro and nanoparticles associated with $P$. gingivalis lipopolysaccharide, an important pathogen for periodontal and periimplant disease $(16,17)$.

To evaluate the influence of titanium particles on cell proliferation, human macrophages were initially cultured in presence of micro and nanoparticles associated or not with lipopolysaccharide from $P$. gingivalis. 
The data showed that macrophages remained viable, proliferative and without alterations of the cell morphology regardless of the particle size and the exposure to PgLPS. Nevertheless, titanium particles were able to induce a pro-inflammatory response characterized by the increased expression of transcripts and proteins for TNF- $\alpha, \mathrm{IL}-1 \beta$ and IL-6 cytokines. Although in the present study the cells were exposed to the same concentration $(50 \mathrm{ng} / \mathrm{mL}$ ) of micro and nanoparticles of titanium, the highest gene expression for all cytokines was found in the nanoparticles group. As described by previous studies $(16,17)$, pro-inflammatory effect can be related to the titanium particle size. Probably because titanium nanoparticles are more efficiently absorbed by macrophages, inducing an intense effect on gene expression (18).

Protein production was higher for IL1- $\beta$ at all time

\section{Cells Viability}

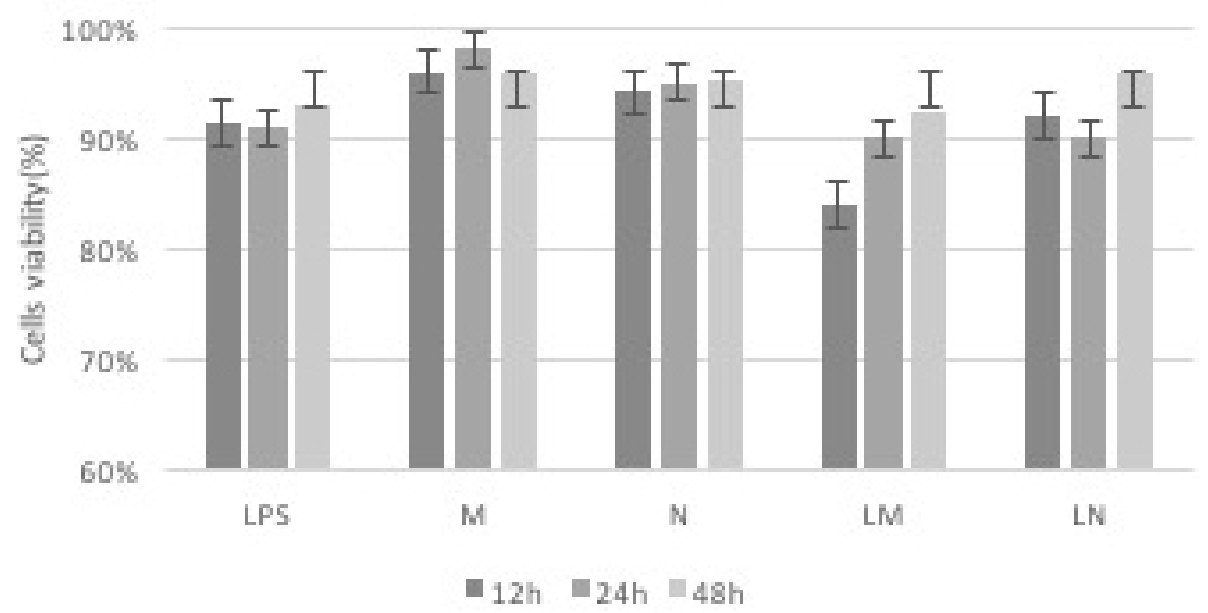

Figure 1. Effect of titanium particles associated or not with $P$. gingivalis lipopolisaccharide on the cell viability. Macrophages were cultured in presence of PgLPS ( $1 \mu \mathrm{g} / \mathrm{mL}$; LPS), titanium microparticles ( $50 \mathrm{ng} / \mathrm{mL} ; \mathrm{M})$, titanium nanoparticles ( $50 \mathrm{ng} / \mathrm{mL}$; N), PgLPS with titanium microparticles (LM) and PgLPS with titanium nanoparticles (LN). Metabolic activity as an indicator for cell viability is represented by absorbance percentage compared to control group after 12, 24 and $48 \mathrm{~h}$ of treatment.
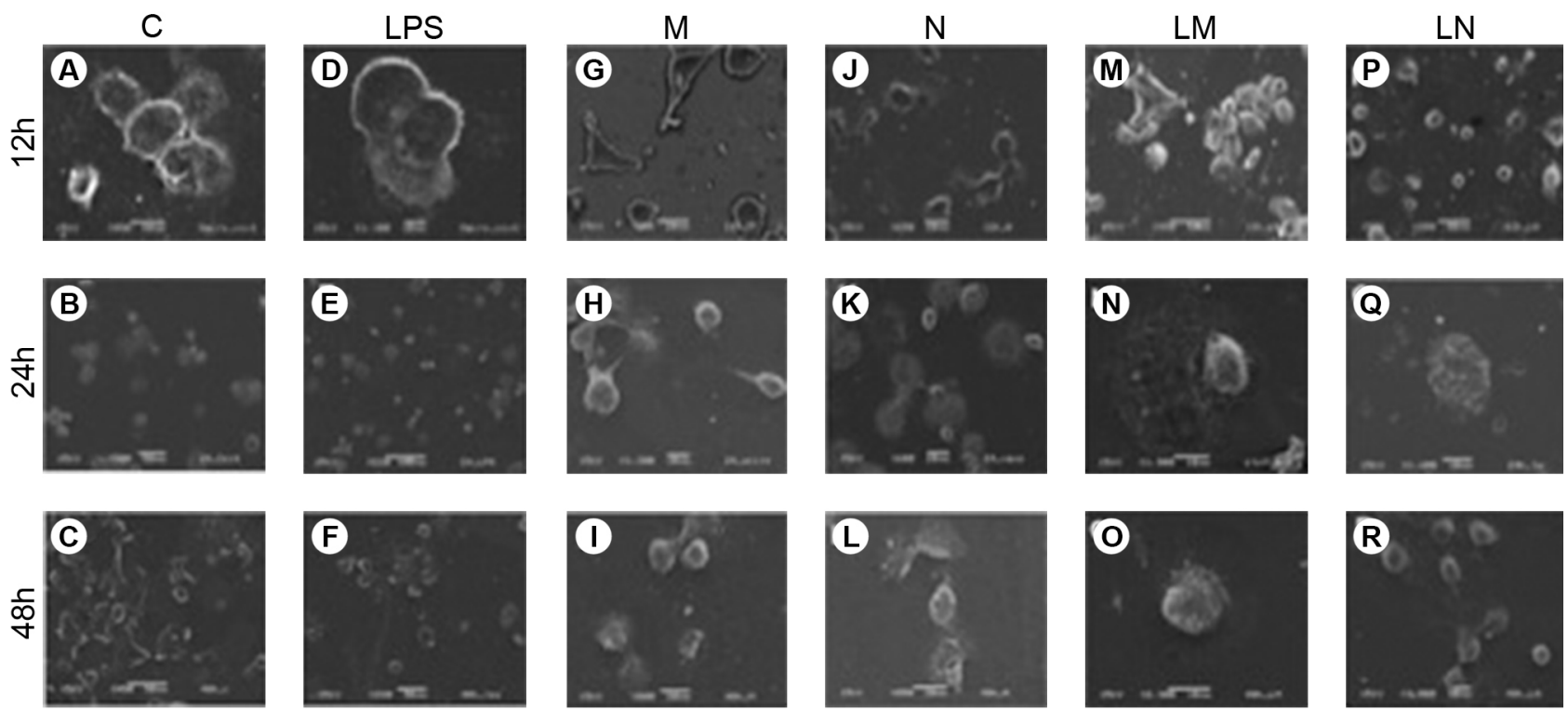

Figure 2. SEM of macrophages after $12 \mathrm{~h}, 24 \mathrm{~h}$ and $48 \mathrm{~h}$ of treatment. (A-C) Control group, without treatment; (D-F) PgLPS at $1 \mu \mathrm{g} / \mathrm{mL}$ concentration; (G-I) Titanium Microparticles - M (50 ng/mL); (J-L) Titanium Nanoparticles - N (50 ng/mL); (M-0) PgLPS with titanium microparticles - LM; (P-R) PgLPS with titanium nanoparticles - LN. 
points and all analyzed groups; this cytokine had a higher production compared to TNF- $\alpha$ and IL-6. However, the analysis of the protein production behavior is more significant than the values of production. IL-1 $\beta$ is the cytokine expressed to start the osteolytic process and plays an important role to TNF- $\alpha$ expression that modulates RANK-L production, leading to bone resorption (19) . Therefore, it was observed that production of TNF- $\alpha$ over time was an ascending curve. If the expression of these protein were analyzed at a later time point, the curve would probably still ascend, as described in a previous study (20). After the production of IL1- $\beta$ and TNF- $\alpha$, IL-6 is produced and this cytokine is related to the recruitment and activation of osteoclasts, which resorb bone $(5,21)$. For IL-6, the production pattern was a straight line between the group treated with titanium nanoparticles that showed

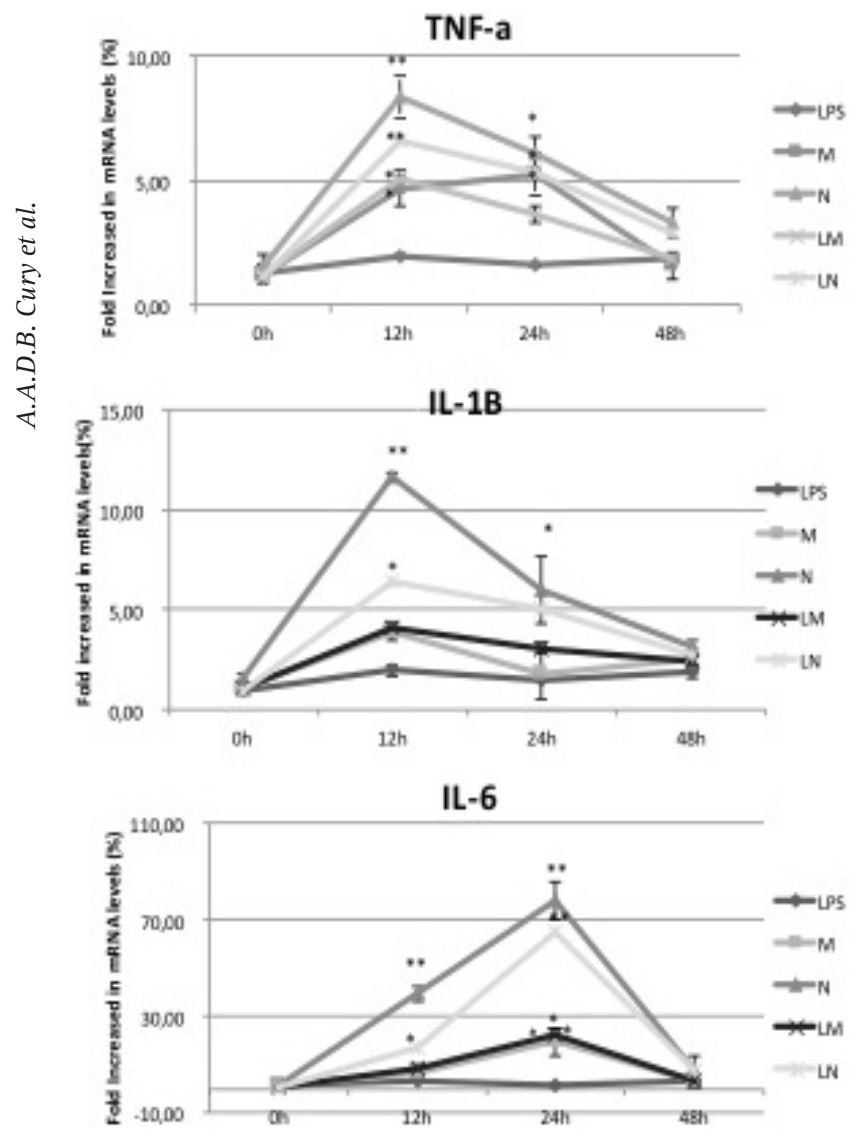

Figure 3. Gene expression analyses of pro-inflammatory cytokines related to osteolysis after $12 \mathrm{~h}, 24 \mathrm{~h}$ and $48 \mathrm{~h}$ of treatment. Fold increased of TNF- $\alpha, I L 1-\beta$ and IL- 6 was compared to the housekeeping gene $(G A P D H)$ and control of each group $(\triangle \Delta \mathrm{Ct})$. Macrophages were cultured in presence of PgLPS ( $1 \mu \mathrm{g} / \mathrm{mL}$; LPS), titanium microparticles (50 ng/mL; M), titanium nanoparticles (50 ng/mL; N), PgLPS with titanium microparticles (LM) and PgLPS with titanium nanoparticles (LN)..* Significant differences from all groups from the same cytokine $(\mathrm{p}<0.05)$ and ${ }^{* *}$ Significant differences from all groups from the same cytokine $(p<0.01)$. Data expressed as mean \pm SD of experiments made in quadruplicate. higher production of cytokines after $48 \mathrm{~h}$, suggesting that nanoparticles could lead to more bone resorption (21).

It was observed that mRNA and cytokine expressions did not present parallel behavior. For example, TNF- $\alpha$ was expressed at $12 \mathrm{~h}$ for $\mathrm{N}, \mathrm{LM}$ and $\mathrm{LN}$ groups and the protein production did not occur at $12 \mathrm{~h}$ or even after $24 \mathrm{~h}$. Another finding was that IL-6 had the highest-fold increase and IL1- $\beta$ produced more proteins. Other studies in the orthopedic literature described similar results to those of present study $(11,15,22)$, but the reasons for this are unknown. A possible explanation may be that this discrepancy in mRNA expression and protein production is related to post-transcriptional processing or autocrine mechanisms to prevent an over-inflammatory reaction that can be harmful for the system (15).

Moreover, other studies showed that titanium particles
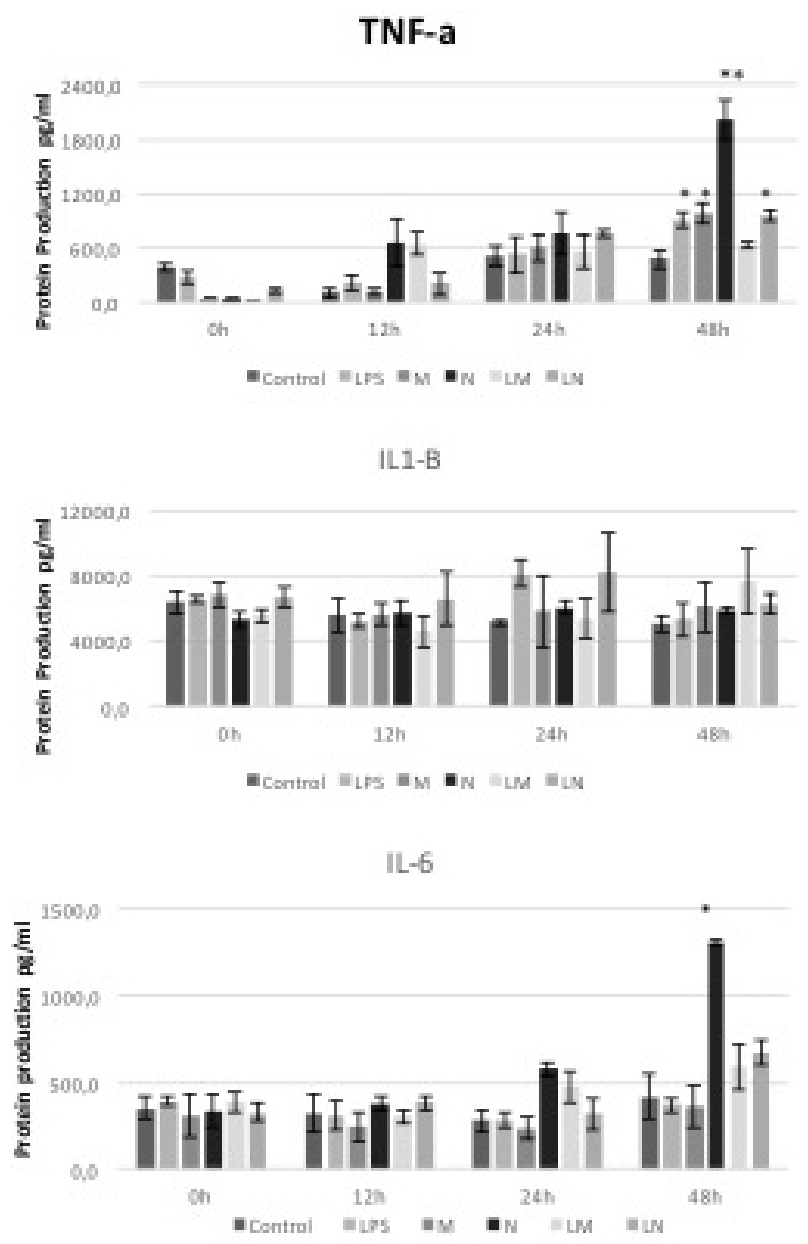

Figure 4. Pro-inflammatory cytokines expression after 12, 24 and $48 \mathrm{~h}$. Macrophages were exposed to PgLPS ( $1 \mu \mathrm{g} / \mathrm{mL}$; LPS), titanium microparticles ( $50 \mathrm{ng} / \mathrm{mL} ; \mathrm{M}$ ), titanium nanoparticles (50 ng/mL; N), PgLPS with titanium microparticles (LM) and PgLPS with titanium nanoparticles (LN). * Significant differences from all groups from the same cytokine $(\mathrm{p}<0.05)$ and ${ }^{* *}$ Significant differences from all groups from the same cytokine $(p<0.01)$. Data expressed as the mean \pm SD of experiments made in triplicate. 
contribute to inflammatory response without the presence of a pathogen, but the endotoxins can exacerbate inflammatory reaction (7). In this study, the association of titanium particles with a pathogen from the oral cavity (PgLPS) did not induce an increased pro-inflammatory response. LPS from $P$. gingivalis is reported not to be as the other Gram-negative bacteria, inducing pro-inflammatory cytokines in several types of cells including the monocyte/ macrophage type $(14,19)$. This is characteristic of $P$. gingivalis that helps the bacteria to invade, without alarming the host immune system (23). Another explanation regarding the lower expression and production of the pro-inflammatory cytokines in presence of PgLPS could be related to the concentration used in this study. The obtained data corroborate the findings of other studies, which assessed the effect of commercial P. gingivalis LPS at $1 \mu \mathrm{g} / \mathrm{mL}$ concentration in human gingival fibroblasts (24) monocytes (25), and human periodontal ligament cells (24). The increased pro-inflammatory response to commercial PgLPS was only found in human periodontal ligament stem cells exposed to high concentration of endotoxin (10 $\mu \mathrm{g} / \mathrm{mL}$ ) (25). This dose-response effect of PgLPS could be related to $P$. gingivalis cell line or to the procedure used to extract LPS (24). Further studies are required to elucidate the inflammatory effect of titanium particles associated to viable bacteria or total extract of $P$. gingivalis.

In this study it was observed that the presence of titanium particles can affect macrophages regarding gene expression and protein production of pro-inflammatory cytokines related to the osteolytic process, mainly in cells exposed to titanium nanoparticles. Moreover, investigations are required on the effect of titanium particles in the process of marginal bone breakdown in dental implants in the early stages of osseointegration. Titanium micro and nanoparticles could have a potential contribution in the bone resorption process leading marginal bone loss.

The presence of titanium particles stimulates the expression and production of pro-inflammatory cytokines TNF- $\alpha$, IL- $1 \beta$ and IL- 6 , which are related to the osteolysis process. Nanoparticles of titanium affect more the proinflammatory reaction. The association with LPS from $P$. gingivalis did not increase gene expression of proinflammatory genes and produced less pro-inflammatory cytokine compared to the groups treated with titanium microparticles and nanoparticles.

In conclusion, the outcomes of the resent study suggest that titanium nanoparticles stimulate a stronger pro-inflammatory response in macrophages, regardless of their association with LPS from $P$. gingivalis.

\section{Resumo}

Durante a inserção de implantes dentários partículas de titânio podem ser liberadas na região peri-implantar levando ao processo de osteólise e a associação com a bactéria pode exacerbar ainda mais a reação inflamatória. Entretanto, a associação de uma bactéria altamente invasiva da cavidade oral, Porphyromonas gingivalis (Pg) e partículas de titânio ainda não foi investigada. Este estudo avaliou a reação pró-inflamatória de macrófagos humanos em contato com micro e nanopartículas de titânio associada a lipopolissacarideo $P$. gingivalis (PgLPS). As células THP-1 foram utilizadas e tratadas durante 12, 24 e $48 \mathrm{~h}$ nos 6 seguintes grupos: Controle (C), PgLPS (L); micropartículas (M); nanopartículas (N); PgLPS e microparticulas (LM); PgLPS e nanopartículas (LN). Em seguida foram realizados os seguintes ensaios: i) a viabilidade celular utilizando MTS, ii) a morfologia celular por MEV e iii) expressão do fator de necrose tumoral alfa (TNF- $\alpha$ ), interleucina-1 beta (IL-1 $\beta$ ) e interleucina 6 (IL-6) por qRT-PCR e ELISA. Como estatística foi realizado o teste ANOVA twoway seguido pelo teste de Tukey $(p<0,05)$. Após o tratamento, as células apresentaram viabilidade e morfologia semelhantes, demonstrando que os tratamentos não foram capazes de induzir a morte celular. A expressão de genes foi significativamente mais elevada para o TNF- $\alpha$ e IL1- $\beta$ após $12 \mathrm{~h}$, e para a IL-6 após 24 horas em N e grupos de LN. A produção de citocinas em relação ao tempo representou uma curva ascendente para o TNF- $\alpha$ com o pico em 48 h, enquanto que para IL1- $\beta$ e IL-6 se apresentou como uma linha reta com relação ao tempo, exceto pelo grupo $\mathrm{N}$ que foi significativo para IL-6 em $48 \mathrm{~h}$. Conclui-se, a partir destes resultados, que as nanopartículas de titânio produziram o maior estímulo na resposta pró-inflamatória nos macrófagos, independente da sua associação com LPS de $P$. gingivalis.

\section{Acknowledgements}

We gratefully acknowledge Dr. Jose Lemos for the support during the development of this study. We also thank Dr. Irlan Almeida, Dr. Jessica K. Kajfasz, Dr. Plinio Senna and James H. Miller for the critical advices. We also acknowledge the São Paulo State Research Foundation (FAPESP) for granting scholarships \#2013/19791-8 and \#2014/10085-6 to the author Dr. Cindy Dodo during the development of this study.

\section{References}

1. Wennerberg A, Albrektsson T. Effects of titanium surface topography on bone integration: a systematic review. Clin Oral Implants Res 2009;20 Suppl 4:172-184.

2. Senna P, Antoninha Del Bel Cury A, Kates S, Meirelles L. Surface damage on dental implants with release of loose particles after insertion into bone. Clin Implant Dent Relat Res 2015;17:681-692.

3. Mints D, Elias C, Funkenbusch P, Meirelles L. Integrity of implant surface modifications after insertion. Int J Oral Maxillofac Impl 2014;29:97104.

4. Flatebo RS, Hol PJ, Leknes KN, Kosler J, Lie SA, Gjerdet NR. Mapping of titanium particles in peri-implant oral mucosa by laser ablation inductively coupled plasma mass spectrometry and high-resolution optical darkfield microscopy. J Oral Pathol Med 2011;40:412-420.

5. Souza PP, Lerner UH. The role of cytokines in inflammatory bone loss. Immunol Invest 2013;42:555-622.

6. Ragab AA, Van De Motter R, Lavish SA, Goldberg VM, Ninomiya JT, Carlin $C R$, et al.. Measurement and removal of adherent endotoxin from titanium particles and implant surfaces. J Orthopaedic Res 1999;17:803-809.

7. Bi Y, Van De Motter RR, Ragab AA, Goldberg VM, Anderson JM, Greenfield EM. Titanium particles stimulate bone resorption by inducing differentiation of murine osteoclasts. J Bone Joint Surg Am 2001;83-A:501-508.

8. Rutar A, Lang NP, Buser D, Burgin W, Mombelli A. Retrospective assessment of clinical and microbiological factors affecting periimplant tissue conditions. Clinical Oral Implants Res 2001;12:189-195.

9. O'Brien-Simpson NM, Burgess K, Brammar GC, Darby IB, Reynolds EC. Development and evaluation of a saliva-based chair-side diagnostic for the detection of Porphyromonas gingivalis. J Oral Microbiol $2015 ; 7: 29129$. 
10. Lee KH, Maiden MF, Tanner AC, Weber HP. Microbiota of successful osseointegrated dental implants. J Periodontol 1999;70:131-138.

11. Schwab LP, Xing Z, Hasty KA, Smith RA. Titanium particles and surfacebound LPS activate different pathways in IC-21 macrophages. J Biomed Mater Res Part B 2006;79:66-73.

12. Jin S, Park JY, Hong JM, Kim TH, Shin HI, Park EK, et al.. Inhibitory effect of (-)-epigallocatechin gallate on titanium particle-induced TNF-alpha release and in vivo osteolysis. Exp Mol Med 2011;43:411-418.

13. Zhang Y, Yu S, Xiao J, Hou C, Li Z, Zhang Z, et al.. Wear particles promote endotoxin tolerance in macrophages by inducing interleukin-1 receptor-associated kinase-M expression. J Biomed Mater Res Part A 2013;101:733-739.

14. Diya Z, Lili C, Shenglai L, Zhiyuan G, Jie Y. Lipopolysaccharide (LPS) of Porphyromonas gingivalis induces IL-1beta, TNF-alpha and IL-6 production by THP-1 cells in a way different from that of Escherichia coli LPS. J Inn Immun 2008;14:99-107.

15. Obando-Pereda GA, Fischer L, Stach-Machado DR. Titanium and zirconia particle-induced pro-inflammatory gene expression in cultured macrophages and osteolysis, inflammatory hyperalgesia and edema in vivo. Life Sci 2014;97:96-106.

16. Zhang Y, Yu W, Jiang X, Lv K, Sun S, Zhang F. Analysis of the cytotoxicity of differentially sized titanium dioxide nanoparticles in murine MC3T3-E1 preosteoblasts. J Mater Sci Mater Med 2011;22:1933-1945.

17. Irshad M, Scheres N, Crielaard W, Loos BG, Wismeijer D, Laine ML. Influence of titanium on in vitro fibroblast - Porphyromonas gingivalis interaction in peri-implantitis. J Clin Periodontol 2013;40:841-849.

18. Sund J, Palomaki J, Ahonen N, Savolainen K, Alenius H, Puustinen A. Phagocytosis of nano-sized titanium dioxide triggers changes in protein acetylation. J. Proteome Res 2014;108:469-483.
19. Ogawa $\mathrm{T}$, Uchida $\mathrm{H}$. Differential induction of IL-1 beta and IL-6 production by the nontoxic lipid A from Porphyromonas gingivalis in comparison with synthetic Escherichia coli lipid A in human peripheral blood mononuclear cells. FEMS Immunol Med Microbiol 1996;14:1-13.

20. Wei $\mathrm{S}$, Kitaura H, Zhou P, Ross FP, Teitelbaum SL. IL-1 mediates TNFinduced osteoclastogenesis. J Clin Invest 2005;115:282-290.

21. Darowish M, Rahman R, Li P, Bukata SV, Gelinas J, Huang W, et al Reduction of particle-induced osteolysis by interleukin-6 involves anti-inflammatory effect and inhibition of early osteoclast precursor differentiation. Bone 2009;45:661-668.

22. Trindade MC, Lind M, Sun D, Schurman DJ, Goodman SB, Smith RL. In vitro reaction to orthopaedic biomaterials by macrophages and lymphocytes isolated from patients undergoing revision surgery. Biomater 2001;22:253-259.

23. Holt SC, Kesavalu L, Walker S, Genco CA. Virulence factors of Porphyromonas gingivalis. Periodontol 2000 1999;20:168-238.

24. Hirschfeld M, Ma Y, Weis JH, Vogel SN, Weis JJ. Cutting edge: repurification of lipopolysaccharide eliminates signaling through both human and murine toll-like receptor 2. J Immunol 2000;165:618-622.

25. Kato $H$, Taguchi $Y$, Tominaga $K$, Umeda M, Tanaka A. Porphyromonas gingivalis LPS inhibits osteoblastic differentiation and promotes proinflammatory cytokine production in human periodontal ligament stem cells. Arch Oral Biol 2014;59:167-175.

Received January 9, 2017 Accepted May 22, 2017 